\title{
STRATEGI KELEMBAGAAN IMPLEMENTASI TEKNOLOGI WakatobiAIS DI KEPULAUAN WAKATOBI
}

\section{Institutional Strategy for Implementing WakatobiAIS Technology in Wakatobi Islands}

\author{
Andi Besse Amir ${ }^{1}$, Sunarwan Asuhadi ${ }^{1}$, Nelly Hidayanti Sarira ${ }^{1}$, Rahmadani ${ }^{2}$ \\ ${ }^{1}$ Loka Perekayasaan Teknologi Kelautan BRSDM KP KKP \\ ${ }^{2}$ Fakultas Perikanan dan Ilmu Kelautan Universitas Halu Oleo \\ ${ }^{1}$ Surel : sunarwan_asuhadi@yahoo.com \\ ${ }^{2}$ Surel : andibesse.amir@gmail.com \\ ${ }^{3}$ Surel : nellyhidayantisarira@gmail.com \\ ${ }^{4}$ Surel : rahmamustafa47@gmail.com
}

\begin{abstract}
Abstrak
Penelitian ini menggunakan pendekatan kualitatif untuk menggambarkan strategi kelembagaan untuk implementasi WakatobiAIS di perairan Kepulauan Wakatobi. Pengumpulan data meliputi angket, studi pustaka, dan wawancara. Pengolahan data menggunakan Stakeholders Mapping, dan Analisis menggunakan SWOT. Hasil penelitian menunjukkan bahwa Pemanfaatan WakatobiAIS di Kabupaten Wakatobi sangat memungkinkan, dibutuhkan kemitraan teknis untuk mewujudkannya, khususnya Syahbandar, LPTK BRSDM KP, Pemerintah Daerah, PSDKP, dan Taman Nasional. Untuk kemitraan tersebut, dibutuhkan inisiatif Pemda Wakatobi untuk mensinergikan kelembagaan yang ada di Wakatobi.
\end{abstract}

Kata kunci : Strategi kelembagaan, Implementasi, WakatobiAIS, Wakatobi

Abstract

This study uses a qualitative approach to describe institutional strategies for the implementation of WakatobiAIS in the waters of the Wakatobi Islands. Data collection includes questionnaires, literature study, and interviews. Data processing using Stakeholders Mapping, and analysis using SWOT. The results showed that the use of WakatobiAIS in Wakatobi Regency is very possible, technical partnerships are needed to make it happen, especially Syahbandar, LPTK BRSDM KP, Local Government, PSDKP, and National Parks. For this partnership, Wakatobi local government initiatives are needed to synergize existing institutions in Wakatobi.

Keywords : Institutional Strategy, Implementing, WakatobiAIS, Wakatobi

\section{Pendahuluan}

Kabupaten Wakatobi dengan visi pembangunan daerah "Mewujudkan Kabupaten Maritim Yang Berdaya Saing", menunjukkan landasan semangat kesadaran kemaritiman atau maritime awareness yang tinggi. Tentu saja ini relevan dengan status wilayah Kabupaten Wakatobi sebagai Taman Nasional Laut dan Cagar Biosfer yang memiliki sumber daya maritim potensial dengan kelimpahan luar biasa, terutama di pesisir dan laut yang belum dimaksimalkan pemanfaatannya.

Posisi Kabupaten Wakatobi sebagai wilayah kepulauan, jalur pelayaran nasional, serta ALKI III menjadikan Perairan Wakatobi sebagai ruang laut yang sangat ramai. Hanya saja pada musim Barat dan Timur, kondisi perairan Wakatobi mendapatkan pengaruh cuaca yang ekstrim sehingga beresiko bagi kegiatan pelayaran. Akumulasi isu dan permasalahan kelautan tersebut, yakni kebutuhan konservasi sampai dengan resiko pelayaran di Perairan Wakatobi merupakan faktor mendasar perlunya sistem pengawasan laut yang memadai untuk memonitor pergerakan kapal besar dan kecil, termasuk aktivitas di perairan yang terindikasi merupakan aktivitas berbahaya dan terlarang.

Salah satu perwujudan dari kebijakan tata kelola kelautan pada level teknis adalah kebijakan Pemasangan dan Pengaktifan Sistem Identifikasi Otomatis Bagi Kapal Yang Berlayar di Wilayah Perairan Indonesia, sebagaimana diatur pada Pasal 5 ayat (1) Peraturan Menteri Perhubungan Republik Indonesia Nomor PM 7 Tahun 2019 tentang Pemasangan dan Pengaktifan Sistem Identifikasi 
Otomatis Bagi Kapal Yang Berlayar di Wilayah Perairan Indonesia.

Pasal 5 ayat (1) PM 7 Tahun 2019 tersebut, menyebutkan bahwa AIS Klas A wajib dipasang dan diaktifkan pada Kapal Berbendera Indonesia yang memenuhi persyaratan Konvensi Safety of Life at Sea (SOLAS) yang berlayar di wilayah Perairan Indonesia. Sedangkan pada ayat (2) menyatakan bahwa AIS Klas B wajib dipasang dan diaktifkan pada Kapal Berbendera Indonesia, yakni (1) pada Kapal penumpang dan Kapal barang Non Konvensi dengan ukuran paling rendah GT 35 (tiga puluh lima Gross Tonnage) yang berlayar di wilayah Perairan Indonesia, (2) pada Kapal yang berlayar antar lintas negara atau yang melakukan barter-trade atau kegiatan lain yang diatur dalam ketentuan peraturan perundang-undangan di bidang kepabeanan, serta (3) pada Kapal penangkap ikan berukuran dengan ukuran paling rendah GT 60 (enam puluh Gross Tonnage).

Pemberlakuan PM 7 Tahun 2019 tersebut, tidak wajib diberlakukan pada kapal barang Non Konvensi dengan ukuran paling di bawah GT 35 dan Kapal penangkap ikan di bawah GT 60. Padahal dalam kenyataannya, kapal-kapal dengan tonnase dibawah ketentuan tersebut (PM 7 Tahun 2019) marak pengoperasiannya di sejumlah daerah, khususnya di wilayah Pulau-Pulau Kecil, misalnya di Kabupaten Wakatobi, dengan tingkat resiko kecelakaan yang demikian tinggi.

Pada tahun 2018, Loka Perekayasaan Teknologi Kelautan (LPTK) BRSDM KP telah memperkenalkan teknologi WakatobiAIS (Wahana Keselamatan dan Pemantauan Objek Berbasis Informasi AIS (Automatic Identification System) yang dapat mengisi kekosongan teknologi nasional untuk pemantauan dan pengawasan kapal kecil, selain yang telah diatur oleh PM 7 Tahun 2019.

WakatobiAIS merupakan teknologi transponder hasil perekayasaan LPTK BRSDM KP, yang berfungsi untuk menginformasikan keberadaan obyek (kapal) laut melalui stasiun pemantauan (base station) yang ada di darat. Di Wakatobi, stasiun pemantauan tersebut dimiliki dan dioperasikan oleh LPTK BRSDM KP. Dalam pemanfaatan teknologi WakatobiAIS tersebut dibutuhkan analisis kelembagaan dan strategi pengimplementasiannya agar memenuhi kebutuhan pelayaran di perairan laut Wakatobi. Hasil penelitian diharapkan dapat menggambarkan tugas dan fungsi teknis kelembagaan di Wakatobi bagi pemanfaatan WakatobiAIS serta strategi pemanfaatan WakatobiAIS di perairan Wakatobi.

\section{Bahan dan Metode}

Penelitian ini dilaksanakan di Kabupaten Wakatobi. Pengumpulan data dilakukan pada beberapa instansi, yakni: LPTK BRSDM KP, Basarnas, Pemerintah Daerah Kabupaten (Bappeda, DKP, dan Dishub), Syahbandar Wakatobi, Taman Nasional Wakatobi, dan PSDKP Wakatobi. Selain itu pengambilan data dilakukan melalui studi pustaka. Adapun waktu pelaksanaannya sejak April s.d. September 2019.

Pengumpulan data meliputi; (1) angket, (2) studi pustaka, dan (3) wawancara dengan pihak-pihak yang relevan. Pengolahan data menggunakan Stakeholders Mapping, dan Analisis menggunakan SWOT.

\section{Hasil dan Pembahasan}

Stakeholders Mapping Untuk

Implementasi WakatobiAIS

Implementasi teknologi

WakatobiAIS memerlukan intervensi dari sejumlah pihak yang memiliki kewenangan, baik terkait dengan kebutuhan riset dan perekayasaan, regulasi dan kewenangan untuk implementasi, regulasi dan kewenangan untuk uji kelaikan, maupun regulasi dan kewenangan untuk penindakan. Berikut ini adalah peta pengaruh masing-masing stakeholders untuk implementasi WakatobiAIS. 
Tabel 1. Peta pengaruh stakeholders untuk implementasi WakatobiAIS

\begin{tabular}{|c|c|c|c|c|c|c|c|c|c|c|c|}
\hline No & akeholders & Eksistensi & Riset & Sertifikasi & Pengadaan & Perizinan & Pengawasan & Penindakan & SAR & Fasilitas & SDM \\
\hline 1. & $\begin{array}{l}\text { Pemerintah } \\
\text { Daerah } \\
\text { Wakatobi }\end{array}$ & $\begin{array}{c}\text { Ada di } \\
\text { Wakatobi }\end{array}$ & $\begin{array}{l}\text { Belum } \\
\text { ada }\end{array}$ & $\begin{array}{l}\text { Tidak Punya } \\
\text { kewenangan }\end{array}$ & $\begin{array}{c}\text { Punya } \\
\text { kewenangan }\end{array}$ & $\begin{array}{c}\text { Punya } \\
\text { kewenangan }\end{array}$ & $\begin{array}{c}\text { Kewenangan } \\
\text { terbatas }\end{array}$ & $\begin{array}{c}\text { Kewenangan } \\
\text { terbatas }\end{array}$ & $\begin{array}{c}\text { Kewenangan } \\
\text { terbatas }\end{array}$ & $\begin{array}{c}\text { Belum } \\
\text { Memadai }\end{array}$ & $\begin{array}{c}\text { Belum } \\
\text { Memadai }\end{array}$ \\
\hline 2. & $\begin{array}{l}\text { Pemerintah } \\
\text { Daerah } \\
\text { Sulawesi } \\
\text { Tenggara }\end{array}$ & $\begin{array}{c}\text { Ada di } \\
\text { Wakatobi }\end{array}$ & $\begin{array}{l}\text { Belum } \\
\text { ada }\end{array}$ & $\begin{array}{l}\text { Tidak Punya } \\
\text { kewenangan }\end{array}$ & $\begin{array}{c}\text { Punya } \\
\text { kewenangan }\end{array}$ & $\begin{array}{c}\text { Punya } \\
\text { kewenangan }\end{array}$ & $\begin{array}{c}\text { Kewenangan } \\
\text { terbatas }\end{array}$ & $\begin{array}{l}\text { Kewenangan } \\
\text { terbatas }\end{array}$ & $\begin{array}{c}\text { Kewenangan } \\
\text { terbatas }\end{array}$ & $\begin{array}{c}\text { Belum } \\
\text { Memadai }\end{array}$ & $\begin{array}{l}\text { Belum } \\
\text { Memadai }\end{array}$ \\
\hline 3. & $\begin{array}{l}\text { Balai Taman } \\
\text { Nasional } \\
\text { Wakatobi }\end{array}$ & $\begin{array}{c}\text { Ada di } \\
\text { Wakatobi }\end{array}$ & $\begin{array}{l}\text { Belum } \\
\text { ada }\end{array}$ & $\begin{array}{l}\text { Tidak Punya } \\
\text { kewenangan }\end{array}$ & $\begin{array}{c}\text { Kewenangan } \\
\text { terbatas }\end{array}$ & $\begin{array}{c}\text { Punya } \\
\text { kewenangan }\end{array}$ & $\begin{array}{c}\text { Kewenangan } \\
\text { terbatas }\end{array}$ & $\begin{array}{l}\text { Kewenangan } \\
\text { terbatas }\end{array}$ & $\begin{array}{c}\text { Kewenangan } \\
\text { terbatas }\end{array}$ & $\begin{array}{c}\text { Belum } \\
\text { Memadai }\end{array}$ & $\begin{array}{l}\text { Belum } \\
\text { Memadai }\end{array}$ \\
\hline 4. & $\begin{array}{l}\text { Syahbandar } \\
\text { (KeMenhub) }\end{array}$ & $\begin{array}{c}\text { Ada di } \\
\text { Wakatobi }\end{array}$ & $\begin{array}{l}\text { Belum } \\
\text { ada }\end{array}$ & $\begin{array}{c}\text { Kewenangan } \\
\text { di Pusat }\end{array}$ & $\begin{array}{c}\text { Punya } \\
\text { kewenangan }\end{array}$ & $\begin{array}{c}\text { Punya } \\
\text { kewenangan }\end{array}$ & $\begin{array}{c}\text { Punya } \\
\text { kewenangan }\end{array}$ & $\begin{array}{c}\text { Punya } \\
\text { kewenangan }\end{array}$ & $\begin{array}{c}\text { Punya } \\
\text { kewenangan }\end{array}$ & $\begin{array}{c}\text { Belum } \\
\text { Memadai }\end{array}$ & $\begin{array}{l}\text { Belum } \\
\text { Memadai }\end{array}$ \\
\hline 5. & $\begin{array}{l}\text { KPLP } \\
\text { (KeMenhub) }\end{array}$ & $\begin{array}{c}\text { Ada di } \\
\text { Wakatobi }\end{array}$ & $\begin{array}{l}\text { Belum } \\
\text { ada }\end{array}$ & $\begin{array}{c}\text { Kewenangan } \\
\text { di Pusat }\end{array}$ & $\begin{array}{c}\text { Kewenangan } \\
\text { terbatas }\end{array}$ & $\begin{array}{c}\text { Kewenangan } \\
\text { terbatas }\end{array}$ & $\begin{array}{c}\text { Punya } \\
\text { kewenangan }\end{array}$ & $\begin{array}{c}\text { Punya } \\
\text { kewenangan }\end{array}$ & $\begin{array}{c}\text { Kewenangan } \\
\text { terbatas }\end{array}$ & $\begin{array}{c}\text { Belum } \\
\text { Memadai }\end{array}$ & $\begin{array}{l}\text { Belum } \\
\text { Memadai }\end{array}$ \\
\hline 6. & Basarnas & $\begin{array}{c}\text { Ada di } \\
\text { Wakatobi }\end{array}$ & $\begin{array}{l}\text { Belum } \\
\text { ada }\end{array}$ & $\begin{array}{c}\text { Kewenangan } \\
\text { di Pusat }\end{array}$ & $\begin{array}{c}\text { Kewenangan } \\
\text { terbatas }\end{array}$ & $\begin{array}{c}\text { Kewenangan } \\
\text { terbatas }\end{array}$ & $\begin{array}{l}\text { Tidak Punya } \\
\text { kewenangan }\end{array}$ & $\begin{array}{l}\text { Tidak Punya } \\
\text { kewenangan }\end{array}$ & $\begin{array}{c}\text { Punya } \\
\text { kewenangan }\end{array}$ & $\begin{array}{l}\text { Belum } \\
\text { Memadai }\end{array}$ & $\begin{array}{l}\text { Belum } \\
\text { Memadai }\end{array}$ \\
\hline 7. & Bakamla & Tidak ada & $\begin{array}{l}\text { Belum } \\
\text { ada }\end{array}$ & $\begin{array}{l}\text { Tidak Punya } \\
\text { kewenangan }\end{array}$ & $\begin{array}{c}\text { Kewenangan } \\
\text { terbatas }\end{array}$ & $\begin{array}{c}\text { Kewenangan } \\
\text { terbatas }\end{array}$ & $\begin{array}{c}\text { Punya } \\
\text { kewenangan }\end{array}$ & $\begin{array}{c}\text { Punya } \\
\text { kewenangan }\end{array}$ & $\begin{array}{c}\text { Punya } \\
\text { kewenangan }\end{array}$ & $\begin{array}{c}\text { Belum ada } \\
\text { (Wakatobi) }\end{array}$ & $\begin{array}{c}\text { Belum ada } \\
\text { (Wakatobi) }\end{array}$ \\
\hline 8. & BNPB & $\begin{array}{c}\text { Ada di } \\
\text { Wakatobi }\end{array}$ & $\begin{array}{l}\text { Belum } \\
\text { ada }\end{array}$ & $\begin{array}{l}\text { Tidak Punya } \\
\text { kewenangan }\end{array}$ & $\begin{array}{c}\text { Kewenangan } \\
\text { terbatas }\end{array}$ & $\begin{array}{c}\text { Kewenangan } \\
\text { terbatas }\end{array}$ & $\begin{array}{l}\text { Tidak Punya } \\
\text { kewenangan }\end{array}$ & $\begin{array}{l}\text { Tidak Punya } \\
\text { kewenangan }\end{array}$ & $\begin{array}{c}\text { Punya } \\
\text { kewenangan }\end{array}$ & $\begin{array}{c}\text { Belum } \\
\text { Memadai }\end{array}$ & $\begin{array}{c}\text { Belum } \\
\text { Memadai }\end{array}$ \\
\hline 9. & PSDKP & $\begin{array}{c}\text { Ada di } \\
\text { Wakatobi }\end{array}$ & $\begin{array}{l}\text { Belum } \\
\text { ada }\end{array}$ & $\begin{array}{l}\text { Tidak Punya } \\
\text { kewenangan }\end{array}$ & $\begin{array}{c}\text { Punya } \\
\text { kewenangan }\end{array}$ & $\begin{array}{c}\text { Punya } \\
\text { kewenangan }\end{array}$ & $\begin{array}{c}\text { Punya } \\
\text { kewenangan }\end{array}$ & $\begin{array}{c}\text { Punya } \\
\text { kewenangan }\end{array}$ & $\begin{array}{c}\text { Kewenangan } \\
\text { terbatas }\end{array}$ & $\begin{array}{c}\text { Belum } \\
\text { Memadai }\end{array}$ & $\begin{array}{c}\text { Belum } \\
\text { Memadai }\end{array}$ \\
\hline 10. & LPTK & $\begin{array}{c}\text { Ada di } \\
\text { Wakatobi }\end{array}$ & Ada & $\begin{array}{l}\text { Tidak Punya } \\
\text { kewenangan }\end{array}$ & $\begin{array}{c}\text { Kewenangan } \\
\text { terbatas }\end{array}$ & $\begin{array}{l}\text { Tidak punya } \\
\text { kewenangan }\end{array}$ & $\begin{array}{l}\text { Tidak Punya } \\
\text { kewenangan }\end{array}$ & $\begin{array}{l}\text { Tidak Punya } \\
\text { kewenangan }\end{array}$ & $\begin{array}{l}\text { Tidak Punya } \\
\text { kewenangan }\end{array}$ & Memadai & Memadai \\
\hline 11. & Polair & $\begin{array}{c}\text { Ada di } \\
\text { Wakatobi }\end{array}$ & $\begin{array}{l}\text { Belum } \\
\text { ada }\end{array}$ & $\begin{array}{l}\text { Tidak Punya } \\
\text { kewenangan }\end{array}$ & $\begin{array}{c}\text { Kewenangan } \\
\text { terbatas }\end{array}$ & $\begin{array}{l}\text { Tidak punya } \\
\text { kewenangan }\end{array}$ & $\begin{array}{c}\text { Punya } \\
\text { kewenangan }\end{array}$ & $\begin{array}{c}\text { Punya } \\
\text { kewenangan }\end{array}$ & $\begin{array}{l}\text { Tidak Punya } \\
\text { kewenangan }\end{array}$ & $\begin{array}{c}\text { Belum } \\
\text { Memadai }\end{array}$ & $\begin{array}{c}\text { Belum } \\
\text { Memadai }\end{array}$ \\
\hline
\end{tabular}


Dari 11 stakeholders yang dianggap punya relevansi untuk implementasi WakatobiAIS di atas, hanya ada 9 lembaga yang sudah berdomisili di Wakatobi (Tabel 1), yakni: Pemerintah Daerah Wakatobi, Pemerintah Daerah Sulawesi Tenggara, Balai Taman Nasional Wakatobi, Syahbandar (KeMenhub), KPLP (KeMenhub), Basarnas, Bakamla, BNPB, PSDKP, LPTK, dan Polair. Dari 9 lembaga tersebut, hanya 1 lembaga yang melaksanakan kegiatan riset dan perekayasaan yang relevan untuk pengembangan WakatobiAIS, yakni Loka Perekayasaan Teknologi Kelautan (LPTK) BRSDM KP, dengan tugas melaksanakan perekayasaan teknologi kelautan di bidang alat dan mesin untuk konservasi dan pengawasan laut, pesisir, dan pulau-pulau kecil berdasarkan Peraturan Menteri Kelautan Dan Perikanan Republik Indonesia Nomor Per.40/Men/2011 Tentang Organisasi Dan Tata Kerja Loka Perekayasaan Teknologi Kelautan.

Dari 9 lembaga tersebut, hanya 2 lembaga yang memiliki kewenangan untuk melakukan sertifikasi terkait peralatan Sarana Bantu Navigasi-Pelayaran, TelekomunikasiPelayaran dan sinyal Mara Bahaya, yakni Kementerian Perhubungan melalui Pengujian dan Sertifikasi Alat Keselamatan Pelayaran oleh Balai Teknologi Keselamatan Pelayaran, serta registrasi dan sertifikasi peralatan pemancar sinyal mara bahaya oleh Badan Nasional Pencarian Dan Pertolongan Republik Indonesia. Untuk kewenangan melakukan pengadaan fasilitas terkait dengan teknologi WakatobiAIS, ada sebanyak 3 lembaga yang terkait, yakni Pemerintah Daerah (Kabupaten/Provinsi), baik melalui Dinas Perhubungan maupun Dinas Kelautan dan Perikanan, serta kelembagaan Syahbandar (Unit Penyelenggara Pelabuhan).

Pasal 87 Undang-Undang Nomor 17 tahun 2008 tentang Pelayaran, menyebutkan bahwa Unit Penyelenggara Pelabuhan mempunyai tugas dan tanggung jawab salah satunya adalah menyediakan dan memelihara Sarana Bantu Navigasi-Pelayaran. Sedangkan peran, tugas, dan wewenang Pemerintah Daerah sebagaimana disebutkan pada Pasal 115 ayat (1) Undang-Undang Nomor 17 tahun 2008 tentang Pelayaran dalam rangka memberikan manfaat untuk sistem pelayaran, di antaranya adalah ikut menjamin keselamatan dan keamanan pelabuhan, menyediakan pusat informasi muatan di tingkat wilayah, dlsb.

Terkait kewenangan Pemerintah Pusat dan Pemerintah Daerah dalam rangka mendukung fasilitas keselamatan nelayan yakni bertanggung jawab terhadap jaminan keselamatan Nelayan dalam melakukan Penangkapan Ikan (Pasal 40 ayat 1 UU 7/2016 tentang Perlindungan dan Pemberdayaan Nelayan, Pembudi Daya Ikan, dan Petambak Garam). Tanggung jawab (terhadap jaminan keselamatan Nelayan dalam melakukan Penangkapan Ikan), yakni memastikan perlengkapan keselamatan bagi Nelayan dalam melakukan Penangkapan Ikan; dan memberikan bantuan pencarian dan pertolongan bagi Nelayan yang mengalami kecelakaan dalam melakukan Penangkapan Ikan secara cepat, tepat, aman, terpadu, dan terkoordinasi (Pasal 40 ayat 2 UU 7/2016 tentang Perlindungan dan Pemberdayaan Nelayan, Pembudi Daya Ikan, dan Petambak Garam).

Untuk perizinan dan pengawasan pelayaran, Pasal 208 ayat (1) dalam melaksanakan fungsi keselamatan dan keamanan, Syahbandar mempunyai tugas: mengawasi kelaiklautan kapal, keselamatan, keamanan dan ketertiban di pelabuhan; mengawasi tertib lalu lintas kapal di perairan pelabuhan dan alur-pelayaran. Pasal 212 ayat (1) Undang-Undang Nomor 17 tahun 2008 tentang Pelayaran, disebutkan bahwa dalam melaksanakan keamanan dan ketertiban di pelabuhan sesuai dengan ketentuan konvensi internasional, Syahbandar bertindak selaku komite keamanan pelabuhan (Port Security Commitee), dan dapat meminta bantuan kepada Kepolisian Republik Indonesia dan/atau Tentara Nasional Indonesia.

$\frac{\frac{\text { Skenario Kebijakan Implementasi }}{\text { WakatobiAIS di Kabupaten Wakatobi }}}{\text { Pada kajian ini, Skenario Kebijakan }}$ Implementasi WakatobiAIS di Kabupaten Wakatobi, dibuat melalui Analisis SWOT atau Analisis KEKEPAN (KekuatanKelemahan, Peluang-Ancaman). Untuk memformulasi Analisis SWOT, maka terlebih dahulu dilakukan identifikasi terkait Faktor Internal dan Faktor Eksternal. Faktor Internal terdiri dari Kekuatan dan Kelemahan, serta faktor eksternal terdiri dari peluang dan ancaman. 
Penilaian Kekuatan yang dimiliki oleh Kabupaten Wakatobi dalam hubungannya dengan Implementasi WakatobiAIS sebagai berikut:

1. S1. Tersedia sejumlah instansi yang berkewenangan pada pengawasan dan keselamatan pemanfaatan laut;

2. S2. Tersedia fasilitas pengawasan dan keselamatan pemanfaatan laut;

3. S3. Wakatobi sebagai Kabupaten Otonom dan Kawasan Konservasi;

4. S4. Wakatobi sebagai Top Ten Destinasi Pariwisata;

5. S5. Wakatobi berada di wilayah ALKI III;

6. S6. Telah dilakukan inisiasi kerjasama stakeholders untuk pemanfaatan teknologi Radar Pantai (AIS);

7. S7. Adanya kewajiban bagi pemerintah untuk mendukung keselamatan nelayan kecil;

8. S.8 Pemerintah memiliki kewajiban menyediakan informasi keamanan dan keselamatan wisatawan;

9. S.9 Secara regulatif setiap instansi memiliki kewenangan untuk melakukan kemitraan.

Penilaian Kelemahan yang dimiliki oleh Kabupaten Wakatobi dalam hubungannya dengan Implementasi WakatobiAIS sebagai berikut:

1. W1. Teknologi pemantauan (base station) bukan instansi Teknis (LPTK);

2. W2. Masih ditemukan egosektoral yang dapat menghambat implementasi pengawasan;

3. W3. Teknologi AIS yang tersedia di pasaran masih dianggap mahal;

4. W4. Informasi mengenai manfaat dan kewajiban AIS belum diketahui luas;

5. W5. Penggunaan AIS untuk nelayan kecil bersifat voluntary;

6. W6. WakatobiAIS belum diproduksi massal.

Penilaian Peluang yang dimiliki oleh Kabupaten Wakatobi dalam hubungannya dengan Implementasi WakatobiAIS adalah sebagai berikut.

1. O1. Telah diwajibkannya penggunaan AIS Kelas A, dan Kelas B (Kapal Penumpang GT 35 dan Kapal Penangkap Ikan GT 60);

2. O2. Pemberlakuan AIS sudah bersifat internasional;
3. O3. Terdapat Ancaman pidana bagi yang tidak patuh untuk implementasi AIS;

4. O4. Masyarakat memiliki hak untuk memberikan masukan terkait implementasi teknologi;

5. O5. Wakatobi memenuhi syarat untuk menjadi area Pelayaran Pandu;

6. O.6.Masyarakat telah menginisiasi pemanfaatan informasi radar LPTK untuk keselamatan pelayaran;

7. O.7.Pengusaha pariwisata memiliki kewajiban untuk keselamatan wisatawan;

8. O.8.TKT WakatobiAIS sudah level 8 . Penilaian Ancaman yang dimiliki oleh Kabupaten Wakatobi dalam hubungannya dengan Implementasi WakatobiAIS sebagai berikut:

1. T1. Adanya penolakan sejumlah kalangan untuk pemberlakuan Wajib AIS;

2. T2. Tumpang tindih regulasi terkait kewenangan pengawasan;

3. T3. Ada rencana moratorium implementasi AIS.

Pada kedua faktor tersebut di atas (internal dan eksternal) dilakukan penilaian dan pembobotan untuk melihat faktor-faktor apa yang memiliki pengaruh. Hasil penilaian dan pembobotan sebagaimana ditunjukkan pada tabel 2. 
Tabel 2. Tabel strategi penerapan teknologi WakatobiAIS

\begin{tabular}{|c|c|c|c|c|c|c|c|c|c|}
\hline \multicolumn{5}{|c|}{ FAKTOR INTERNAL } & \multicolumn{5}{|c|}{ FAKTOR EKSTERNAL } \\
\hline & Penilaian Kekuatan $(\mathbf{S})$ & Bobot & Nilai & NT & & $\begin{array}{c}\text { Penilaian Peluang }(\mathbf{O}) \\
\end{array}$ & Bobot & Nilai & NT \\
\hline S1. & $\begin{array}{l}\text { Tersedia sejumlah instansi yang berkewenangan pada pengawasan dan } \\
\text { keselamatan pemanfaatan laut }\end{array}$ & 10 & 4 & 40 & O1. & $\begin{array}{l}\text { Telah diwajibkannya penggunaan AIS Kelas A, dan Kelas B } \\
\text { (Kapal Penumpang GT } 35 \text { dan Kapal Penangkap Ikan } \sim \text { GT } \\
60 \text { ) }\end{array}$ & 15 & 5 & 75 \\
\hline S2. & Tersedia fasilitas pengawasan dan keselamatan pemanfaatan laut & 15 & 5 & 75 & $\mathrm{O} 2$. & Pemberlakuan AIS sudah bersifat internasional & 5 & 3 & 15 \\
\hline S3. & Wakatobi sebagai Kabupaten Otonom dan Kawasan Konservasi & 15 & 5 & 75 & $\mathrm{O} 3$. & $\begin{array}{l}\text { Terdapat Ancaman pidana bagi yang tidak patuh untuk } \\
\text { implementasi AIS }\end{array}$ & 15 & 4 & 60 \\
\hline S4. & Wakatobi sebagai Top Ten Destinasi Pariwisata & 15 & 5 & 75 & O4. & $\begin{array}{l}\text { Masyarakat memiliki hak untuk memberikan masukan terkait } \\
\text { implementasi teknologi }\end{array}$ & 15 & 3 & 45 \\
\hline S5. & Wakatobi berada di wilayah ALKI III A dan III B & 10 & 3 & 30 & O5. & $\begin{array}{l}\text { Wakatobi memenuhi syarat untuk menjadi area Pelayaran } \\
\text { Pandu }\end{array}$ & 15 & 4 & 60 \\
\hline s6. & $\begin{array}{l}\text { Telah dilakukan inisiasi kerjasama stakeholders untuk pemanfaatan } \\
\text { teknologi Radar Pantai (AIS) }\end{array}$ & 10 & 4 & 40 & O.6. & $\begin{array}{l}\text { Masyarakat telah menginisiasi pemanfaatan informasi radar } \\
\text { LPTK untuk keselamatan pelayaran }\end{array}$ & 15 & 4 & 60 \\
\hline S7. & $\begin{array}{l}\text { Adanya kewajiban bagi pemerintah untuk mendukung keselamatan } \\
\text { nelayan kecil }\end{array}$ & 15 & 5 & 75 & O.7. & $\begin{array}{l}\text { Pengusaha pariwisata memiliki kewajiban untuk keselamatan } \\
\text { wisatawan }\end{array}$ & 15 & 5 & 75 \\
\hline S.8 & $\begin{array}{l}\text { Pemerintah memiliki kewajiban menyediakan informasi keamanan dan } \\
\text { keselamatan wisatawan }\end{array}$ & 5 & 4 & 20 & 0.8 . & TKT Mini AIS (Wakatobi AIS) sudah level 8 & 5 & 4 & 20 \\
\hline \multirow[t]{3}{*}{ S.9 } & $\begin{array}{l}\text { Secara regulatif setiap instansi memiliki kewenangan untuk melakukan } \\
\text { kemitraan }\end{array}$ & 5 & 4 & 20 & & & & & \\
\hline & & 100 & 39 & 450 & & & 100 & 32 & 410 \\
\hline & Penilaian Kelemahan (W) & Bobot & Nilai & NT & & Penilaian Ancaman (T) & Bobot & Nilai & NT \\
\hline W1. & Teknologi pemantauan (Base Station) bukan instansi Teknis (LPTK) & 20 & 3 & 60 & T1. & $\begin{array}{l}\text { Adanya penolakan sejumlah kalangan untuk pemberlakuan } \\
\text { Wajib AIS }\end{array}$ & 30 & 4 & 120 \\
\hline W2. & $\begin{array}{l}\text { Masih ditemukan egosektoral yang dapat menghambat implementasi } \\
\text { pengawasan }\end{array}$ & 20 & 5 & 100 & $\mathrm{~T} 2$. & Tumpang tindih regulasi terkait kewenangan pengawasan & 30 & 4 & 120 \\
\hline W3. & Teknologi AIS yang tersedia di pasaran masih dianggap mahal & 15 & 5 & 75 & T3. & Ada rencana moratorium implementasi AIS & 40 & 4 & 160 \\
\hline W4. & Informasi mengenai manfaat dan kewajiban AIS belum diketahui luas & 10 & 4 & 40 & & & & & \\
\hline W5. & Penggunaan AIS untuk nelayan kecil bersifat voluntary & 20 & 5 & 100 & & & & & \\
\hline \multirow[t]{2}{*}{ W6. } & Mini AIS (Wakatobi AIS) belum diproduksi massal & 15 & 22 & 375 & & & & 12 & 0 \\
\hline & & 100 & & 750 & & & 100 & & 400 \\
\hline
\end{tabular}


Tabel 3. Matriks SWOT untuk Strategi Penerapan Inovasi Teknologi (WakatobiAIS) di Kabupaten Wakatobi

\begin{tabular}{|c|c|c|}
\hline EFAS IFAS & $\begin{array}{r}\text { Strenghts (S) } \\
\text { S1, S2,...S9 }\end{array}$ & $\begin{array}{l}\text { Weaknesss }(\mathrm{W}) \\
\text { W1, W2,..W6 }\end{array}$ \\
\hline $\begin{array}{l}\text { Opportunities }(0) \\
\text { O1 }\end{array}$ & Strategi SO & Strategi WO \\
\hline $\begin{array}{l}\mathbf{O 2} \\
\cdot \\
08\end{array}$ & $\begin{array}{l}\text { Pemda Wakatobi perlu memanfaatkan posisi } \\
\text { Kabupaten Wakatobi sebagai Kabupaten } \\
\text { Otonom, kawasan konservasi, Top Ten } \\
\text { Destinasi Pariwisata, alur ALKI serta } \\
\text { keberadaan instansi berwenang dalam } \\
\text { pemanfaatan laut yang telah eksis, fasilitas } \\
\text { pengawasan, maupun penguatan kemitraan } \\
\text { yang sudah berjalan untuk mendorong } \\
\text { implementasi WakatobiAIS secara luas di } \\
\text { Wakatobi, serta usulan penetapan Wakatobi } \\
\text { sebagai area pelayaran pandu untuk } \\
\text { memenuhi keselamatan dan keamanan } \\
\text { pelayaran, termasuk nelayan kecil dan para } \\
\text { wisatawan (S1, S2, S3, S4, S5, S6, S7, S8, } \\
\text { S9, O1, O2, O3, O4, O5, O6, O7,O8). }\end{array}$ & $\begin{array}{l}\text { Pemda Wakatobi perlu mendorong } \\
\text { pemanfaatan bersama base station radar } \\
\text { LPTK, implementasi WakatobiAIS secara } \\
\text { luas sebagai salah satu branding Wakatobi, } \\
\text { serta usulan penetapan Wakatobi sebagai } \\
\text { area pelayaran pandu untuk mendukung } \\
\text { keselamatan dan pengawasan pelayaran, } \\
\text { aktivitas nelayan, serta kepariwisataan (W1, } \\
\text { W2, W3, W4, W5, W6, O1, O2, O3, O4, O5, } \\
\text { O6, O7,O8). }\end{array}$ \\
\hline $\begin{array}{l}\text { Treaths }(\mathrm{T}) \\
\text { T1 }\end{array}$ & Strategi ST & Strategi WT \\
\hline $\begin{array}{l}\text { T2 } \\
\cdot \\
\text { T3 }\end{array}$ & $\begin{array}{l}\text { Pemda Wakatobi perlu memanfaatkan posisi } \\
\text { Kabupaten Wakatobi sebagai Kabupaten } \\
\text { Otonom, kawasan konservasi, Top Ten } \\
\text { Destinasi Pariwisata, alur ALKI serta } \\
\text { keberadaan instansi berwenang dalam } \\
\text { pemanfaatan laut yang telah eksis, fasilitas } \\
\text { pengawasan, maupun penguatan kemitraan } \\
\text { yang sudah berjalan untuk mendorong } \\
\text { kesadaran dan implementasi WakatobiAIS } \\
\text { secara luas di Wakatobi, untuk mendukung } \\
\text { nelayan dan para wisatawan (S1, S2, S3, S4, } \\
\text { S5, S6, S7, S8, S9, T1, T2, T3). }\end{array}$ & $\begin{array}{l}\text { Pemda Wakatobi perlu mendorong } \\
\text { pemanfaatan bersama base station radar } \\
\text { LPTK, implementasi WakatobiAIS secara } \\
\text { luas sebagai salah satu branding Wakatobi, } \\
\text { untuk mendukung keselamatan dan } \\
\text { pengawasan pelayaran, aktivitas nelayan, } \\
\text { serta kepariwisataan (W1, W2, W3, W4, W5, } \\
\text { W6, T1, T2, T3). }\end{array}$ \\
\hline
\end{tabular}


Dari Matriks SWOT untuk Strategi Penerapan Inovasi Teknologi (WakatobiAIS) di Kabupaten Wakatobi di atas, maka dibuat Prioritas Untuk Strategi Penerapan Inovasi Teknologi (WakatobiAIS) di Kabupaten Wakatobi (Tabel 3).

Tabel 4. Penentuan Prioritas Untuk Strategi Penerapan Inovasi Teknologi (WakatobiAIS) di Kabupaten Wakatobi

\begin{tabular}{|c|c|c|c|}
\hline NO & STRATEGI & NILAI & PRIORITAS \\
\hline 1 & $\begin{array}{l}\text { Pemda Wakatobi perlu memanfaatkan posisi Kabupaten } \\
\text { Wakatobi sebagai Kabupaten Otonom, kawasan konservasi, } \\
\text { Top Ten Destinasi Pariwisata, alur ALKI serta keberadaan } \\
\text { instansi berwenang dalam pemanfaatan laut yang telah eksis, } \\
\text { fasilitas pengawasan, maupun penguatan kemitraan yang } \\
\text { sudah berjalan untuk mendorong implementasi WakatobiAIS } \\
\text { secara luas di Wakatobi, serta usulan penetapan Wakatobi } \\
\text { sebagai area pelayaran pandu untuk memenuhi keselamatan } \\
\text { dan keamanan pelayaran, termasuk untuk nelayan kecil dan } \\
\text { para wisatawan. }\end{array}$ & $\begin{array}{l}(\mathrm{S} 1+\mathrm{S} 2+\mathrm{S} 3+\mathrm{S} 4+\mathrm{S} 5+\mathrm{S} 6 \\
+\mathrm{S} 7+\mathrm{S} 8+\mathrm{S} 9+\mathrm{O} 1+\mathrm{O} 2+ \\
\mathrm{O} 3+\mathrm{O} 4+\mathrm{O} 5+\mathrm{O} 6+\mathrm{O} 7+ \\
\mathrm{O} 8) \\
39+32=71\end{array}$ & I \\
\hline 2 & $\begin{array}{l}\text { Pemda Wakatobi perlu memanfaatkan posisi Kabupaten } \\
\text { Wakatobi sebagai Kabupaten Otonom, kawasan konservasi, } \\
\text { Top Ten Destinasi Pariwisata, alur ALKI serta keberadaan } \\
\text { instansi berwenang dalam pemanfaatan laut yang telah eksis, } \\
\text { fasilitas pengawasan, maupun penguatan kemitraan yang } \\
\text { sudah berjalan untuk mendorong kesadaran dan implementasi } \\
\text { WakatobiAIS secara luas di Wakatobi, untuk mendukung } \\
\text { nelayan dan para wisatawan. }\end{array}$ & $\begin{array}{l}(\mathrm{S} 1+\mathrm{S} 2+\mathrm{S} 3+\mathrm{S} 4+\mathrm{S} 5+\mathrm{S} 6 \\
+\mathrm{S} 7+\mathrm{S} 8+\mathrm{S} 9+\mathrm{T} 1+\mathrm{T} 2+ \\
\mathrm{T} 3) \\
39+12=51\end{array}$ & III \\
\hline 3 & $\begin{array}{l}\text { Pemda Wakatobi perlu mendorong pemanfaatan bersama } \\
\text { base station radar LPTK, implementasi WakatobiAIS secara } \\
\text { luas sebagai salah satu branding Wakatobi, serta usulan } \\
\text { penetapan Wakatobi sebagai area pelayaran pandu untuk } \\
\text { mendukung keselamatan dan pengawasan pelayaran, aktivitas } \\
\text { nelayan, serta kepariwisataan. }\end{array}$ & $\begin{array}{l}(\mathrm{W} 1+\mathrm{W} 2+\mathrm{W} 3+\mathrm{W} 4+\mathrm{W} 5 \\
+\mathrm{W} 6+\mathrm{O} 1+\mathrm{O} 2+\mathrm{O} 3+\mathrm{O} 4+ \\
\mathrm{O} 5+\mathrm{O} 6+\mathrm{O} 7+\mathrm{O} 8) \\
22+32=54\end{array}$ & II \\
\hline 4 & $\begin{array}{l}\text { Pemda Wakatobi perlu mendorong pemanfaatan bersama } \\
\text { base station radar LPTK, implementasi WakatobiAIS secara } \\
\text { luas sebagai salah satu branding Wakatobi, untuk mendukung } \\
\text { keselamatan dan pengawasan pelayaran, aktivitas nelayan, } \\
\text { serta kepariwisataan. }\end{array}$ & $\begin{array}{l}(\mathrm{W} 1+\mathrm{W} 2+\mathrm{W} 3+\mathrm{W} 4+\mathrm{W} 5 \\
+\mathrm{W} 6+\mathrm{T} 1+\mathrm{T} 2+\mathrm{T} 3) \\
22+12=34\end{array}$ & IV \\
\hline
\end{tabular}




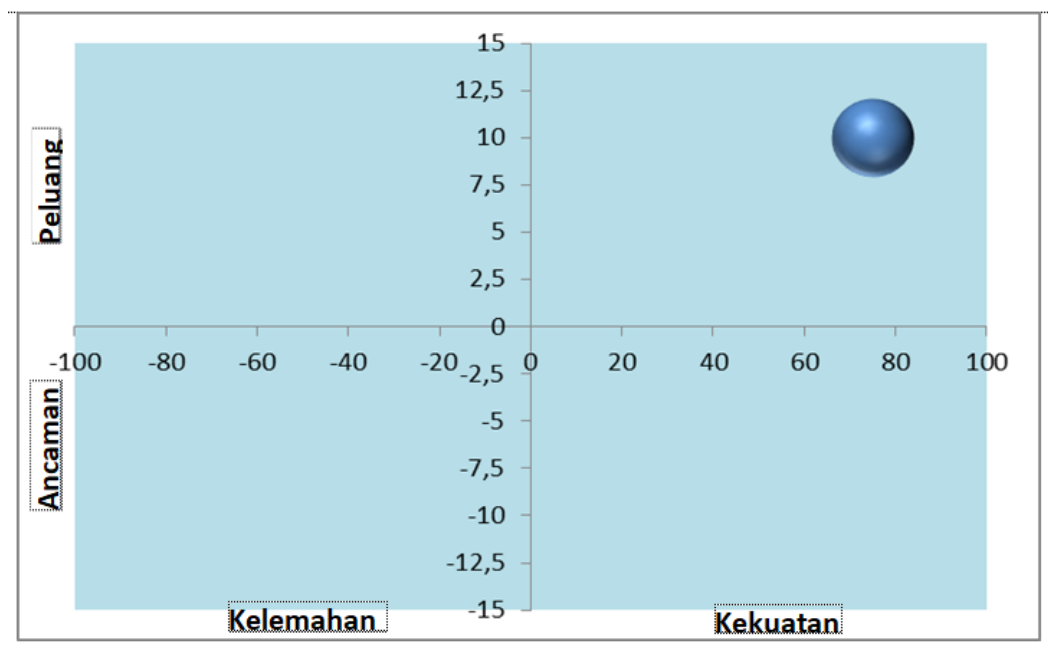

Gambar 1. Posisi kuadran hasil analisa SWOT

Hasil Penilaian dan Pembobotan menunjukkan posisi strategi yang akan dilakukan, apakah berada pada kuadran I, II, III, dan/atau IV. Hasil penilaian dan pembobotan untuk analisa SWOT pada kajian implementasi teknologi inovasi WakatobiAIS menunjukkan berada pada kuadran I, yakni dikontribusi oleh faktorfaktor positif (progresif), yakni dari nilai kekuatan dan peluang.

Berdasarkan hasil penilaian dan pembobotan faktor-faktor internal dan eksternal, maka dapat dibuat matriks SWOT untuk Strategi Penerapan Inovasi Teknologi (WakatobiAIS) di Kabupaten Wakatobi, sebagaimana pada tabel berikut.

Formasi Kelembagaan Untuk Implementasi WakatobiAIS di Wakatobi

Berdasarkan analisis stakeholders mapping untuk implementasi inovasi teknologi WakatobiAIS, didapatkan beberapa aktor kunci dan strategis, yakni: 9 lembaga berdomisili di Wakatobi, 1 lembaga yang melakukan riset (LPTK), 2 lembaga yang memiliki kewenangan untuk sertifikasi (KeMenhub dan Basarnas), 3 lembaga yang memiliki akses kewenangan untuk pengadaan (Pemerintah Daerah Kabupaten dan Provinsi, dan Syahbandar), 5 lembaga yang melakukan perizinan (Pemerintah Daerah Kabupaten dan Provinsi, Taman Nasional, Syahbandar, dan PSDKP), 3 lembaga yang melakukan pengawasan dan penindakan (Syahbandar, PSDKP, Polair), 3 lembaga yang memiliki akses kewenangan untuk kebutuhan pencarian dan pertolongan
(Syahbandar, Basarnas, BNPB), dan 1 lembaga yang memiliki fasilitas dan SDM yang memadai (LPTK). Dengan demikian, aktor-aktor kunci adalah Syahbandar, LPTK BRSDM KP, Pemerintah Daerah, PSDKP, dan Taman Nasional. Oleh karena itu, formasi kemitraan kelembagaan yang hendaknya diinisiasi adalah kemitraan yang melibatkan aktor-aktor kunci ini, dengan inisiator yang bisa menjadi fasilitator kemitraan adalah salah satu dari keempat aktor kunci tersebut.

Kemitraan tersebut, hendaknya menjadikan LPTK BRSDM KP tetap sebagai pusat kemitraan, oleh karena telah memiliki sistem, fasilitas, dan SDM yang sudah berjalan, sampai dengan adanya fasilitas baru yang lebih memadai. Ruang lingkup kedudukan, tugas, fungsi, dan wewenangn kelembagaan kemitraan tersebut dapat diformulasi setelah terbentuk sesuai peraturan perundang-undangan yang berlaku.

\section{Kesimpulan}

Pemanfaatan WakatobiAIS di Kabupaten Wakatobi sangat memungkinkan, dibutuhkan kemitraan teknis untuk mewujudkannya, khususnya Syahbandar, LPTK BRSDM KP, Pemerintah Daerah, PSDKP, dan Taman Nasional. Untuk kemitraan tersebut, dibutuhkan inisiatif Pemda Wakatobi untuk mensinergikan kelembagaan yang ada di Wakatobi. 


\section{Ucapan Terima Kasih}

Kami ucapkan terima kasih kepada Kepala Loka Perekayasaan Teknologi Kelautan Wakatobi yang telah memberikan dukungan dan semangat dalam penyelesaian karya tulis ini, juga ucapan terima kasih kepada para pegawai dan staf dari lembaga/instansi yang telah menjadi mitra atas segala bantuannya secara teknis sehingga penelitian dan penulisan jurnal ini dapat terselesaikan.

\section{Daftar Pustaka}

Bappeda Wakatobi, 2017. Studi Potensi Pengembangan Sumberdaya Maritim (Laporan Akhir Dokumen Kelitbangan Bappeda Wakatobi Tahun 2017)

DKP Wakatobi, 2017. Laporan Akhir Pembuatan Grand Desain Pengembangan Perikanan Wakatobi.

Fis Purwangka, dkk. Kebijakan Internasional Mengenai Keselamatan Nelayan (International Safety Policy on Fishermen). Buletin PSP ISSN: 0251286X, Volume 21 No. 1 Edisi April 2013, Hal 51-65.

Hisyam, M.S., 1998. Analisa SWOT Sebagai Langkah Awal Perencanaan Usaha. Makalah. Jakarta : SEM Institute.

Howlett, Michael and M. Ramesh. 1995.Studying Public Policy: Policy Cyclesand Policy Subsystem.Oxford : Oxford University Press.

Kadarisman, M. 2017. Kebijakan Keselamatan Dan Keamanan Maritim Dalam Menunjang Sistem Transportasi Laut. Jurnal Manajemen Transportasi \& Logistik - Vol. 04 No. 02, Juli 2017, ISSN 2355-4721.

Keputusan Menteri Dalam Negeri RI No. 4/2/3/Um tentang Penetapan Polisi Perairan sebagai Bagian dari Djawatan Kepolisian Negara

Keputusan Menteri Dalam Negeri RI No.4 / 2 / 3 / Um tentang Penetapan Polisi Perairan sebagai Bagian dari Djawatan Kepolisian Negara

Keputusan Menteri Kehutanan Republik Indonesia Nomor 393/Kpts-IV/1996 tentang Penunjukan Kawasan Kepulauan Wakatobi Dan Perairan Laut Di Sekitarnya Di Kabupaten Daerah Tingkat II Buton, Propinsi Daerah Tingkat I Sulawesi Tenggara Seluas \pm 1.390 .000$
(Satu Juta Tiga Ratus Sembilan Puluh Ribu) Hektar Sebagai Taman Nasional.

Keputusan Menteri Kehutanan Republik Indonesia Nomor 7651/Kpts-II/2002 tentang Penetapan Kawasan Kepulauan Wakatobi dan Perairan Laut di Sekitarnya Seluas 1.390.000 (Satu Juta Tiga Ratus Sembilan Puluh Ribu) Hektar. Keputusan Menteri Kelautan dan Perikanan Republik Indonesia Nomor 5/KEPMENKP/2014 tentang Kawasan Konservasi Perairan Nasional Laut Sawu dan Sekitarnya di Provinsi Nusa Tenggara Timur.

Kusumanegara, Solahuddin. 2010.Model dan Aktor dalam Proses Kebijakan Publik. Yoyakarta: Gava Media.

Laporan Akhir Kegiatan Perekayasaan Teknologi Pengawasan Laut Loka Perekayasaan Teknologi Kelautan (LPTK) Tahun Anggaran.

LPTK dan Solusi 247. 2017. Laporan Akhir Kegiatan Rancang Bangun Teknologi Pewngawasan Laut Tahun 2017.

LPTK dan Solusi 247. 2018. Laporan Akhir Kegiatan Rancang Bangun Teknologi Pewngawasan Laut Tahun 2018.

Mathur, V.N., et al, 2007. Defining, identifying and mapping stakeholders in the assessment of urban sustainability. IN: Horner, M. ... et al (eds.). Proceedings: SUE-MoT Conference 2007: International Conference on Whole Life Sustainability and its Assessment, Glasgow, Scotland, 27th-29th June 2007.

Peraturan Menteri Perhubungan Republik Indonesia Nomor PM 7 Tahun 2019 Tentang Pemasangan Dan Pengaktifan Sistem Identifikasi Otomatis Bagi Kapal Yang Berlayar Di Wilayah Perairan Indonesia

Peraturan Badan Nasional Pencarian Dan Pertolongan Republik Indonesia, Nomor 15 Tahun 2018 tentang Tata Kelola Sistem Komunikasi Pencarian Dan Pertolongan Di Lingkungan Badan Nasional Pencarian dan Pertolongan

Peraturan Menteri Kelautan dan Perikanan Republik Indonesia No. PER.17/MEN/2008 tentang Kawasan Konservasi di Wilayah Pesisir dan PulauPulau Kecil

Peraturan Menteri Kelautan dan Perikanan Republik Indonesia Nomor 
PER.02/MEN/2009 tentang Tata Cara Penetapan Kawasan Konservasi Perairan.

Peraturan Menteri Kelautan Dan Perikanan Republik Indonesia Nomor Per.40/Men/2011 Tentang Organisasi Dan Tata Kerja Loka Perekayasaan Teknologi Kelautan.

Peraturan Menteri Kelautan Dan Perikanan Republik Indonesia Nomor 18/PERMEN-KP/2014 Tentang Wilayah Pengelolaan Perikanan Negara Republik Indonesia

Peraturan Menteri Nomor 42 Tahun 2016 tentang Pengukuran dan Penetapan Tingkat Kesiapterapan Teknologi.

Peraturan Menteri Perhubungan Republik Indonesia Nomor PM 57 Tahun 2015 Tentang Pemanduan Dan Penundaan Kapal

Peraturan Presiden Republik Indonesia Nomor 178 Tahun 2014 tentang Badan Keamanan Laut

Purwangka, F, dkk. Kebijakan Internasional Mengenai Keselamatan Nelayan (International Safety Policy on Fishermen). Buletin PSP ISSN: 0251286X, Volume 21 No. 1 Edisi April 2013.

Rangkuti, Freddly, ; Analisis SWOT Teknik Membedah Kasus Bisnis. Jakarta, PT. Gramedia Pustaka Utama, 2004.

Sopari, Hery, Putu Oka, Ngakan, Salman, Darmawan, Model Kolaborasi Perencanaan Anatara Balai Taman Nasional Wakatobi Dan Pemerintah Kabupaten Wakatobi Dalam Pengelolaan Sumber Daya Alam Hayati Secara Lestari. J. Sains \& Teknologi, Agustus 2014, Vol.14 No.2 : 189 - 198.

Surat Edaran Direktorat Jenderal Perhubungan Laut Kementerian Perhubungan, No. SE.29 Tahun 2019 tentang Pelaksanaan Pengujian dan Sertifikasi Alat Keselamatan Pelayaran

Umar, H. Hukum Maritim dan MasalahMasalah Pelayaran di Indoneisa: Buku II, Pustaka Sinar Harapan, Jakarta, 2001.

Undang Undang Republik Indonesia Nomor 24 Tahun 2007 Tentang Penanggulangan Bencana

Undang Undang Republik Indonesia Nomor 5 Tahun 1990 Tentang Konservasi Sumberdaya Alam Hayati Dan Ekosistemnya
Undang-Undang Republik Indonesia Nomor 1 Tahun 2014 Tentang Perubahan Atas Undang-Undang Nomor 27 Tahun 2007 Tentang Pengelolaan Wilayah Pesisir dan Pulau-Pulau Kecil

Undang-Undang Republik Indonesia Nomor 10 Tahun 2009 tentang Kepariwisataan

Undang-Undang Republik Indonesia Nomor 12 Tahun 2011 tentang Pembentukan Peraturan Perundang-Undangan.

Undang-Undang Republik Indonesia Nomor 17 Tahun 2008 tentang Pelayaran

Undang-Undang Republik Indonesia Nomor 18 Tahun 2002 Tentang Sistem Nasional Penelitian, Pengembangan, Dan Penerapan Ilmu Pengetahuan dan Teknologi

Undang-Undang Republik Indonesia Nomor 2 Tahun 2002 Tentang Kepolisian Negara Republik Indonesia

Undang-Undang Republik Indonesia Nomor 23 Tahun 2014 tentang Pemerintahan Daerah

Undang-Undang Republik Indonesia Nomor 24 Tahun 2007 Tentang Penanggulangan Bencana

Undang-Undang Republik Indonesia Nomor 27 Tahun 2007 tentang Pengelolaan Wilayah Pesisir dan Pulau-Pulau Kecil.

Undang-Undang Republik Indonesia Nomor 29 Tahun 2003 tentang Pembentukan Kabupaten Bombana, Kabupaten Wakatobi, dan Kabupaten Kolaka Utara di Provinsi Sulawesi Tenggara.

Undang-Undang Republik Indonesia Nomor 29 Tahun 2003 tentang Pembentukan Kabupaten Bombana, Kabupaten Wakatobi, dan Kabupaten Kolaka Utara di Provinsi Sulawesi Tenggara

Undang-Undang Republik Indonesia Nomor 29 Tahun 2014 Tentang Pencarian Dan Pertolongan.

Undang-Undang Republik Indonesia Nomor 32 tahun 2004 tentang Pemerintahan Daerah

Undang-Undang Republik Indonesia Nomor 7 Tahun 2016 Tentang Perlindungan dan Pemberdayaan Nelayan, Pembudi Daya Ikan, dan Petambak Garam

Yusuf, M., 2012. Tren tangkapan Tuna di Wakatobi.https://www.wwf.or.id/?24941 /tren-tang\%2520kapan-tuna-di-wakatobi (23 April 2012). 